Business Review- A Journal of Business Administration Discipline, Khulna University, Volume: 13, Number: 1E2,January-December 2018, pp.13-28 (Print ISSN : 1811-3788; Online ISSN : 2664-3502)

\title{
business Analysis of Consumer Purchase Intention of Life Insurance: Bangladesh Perspective
}

\author{
${ }^{1}$ Tasmin Jahan and ${ }^{2} \mathrm{Md}$. Mahiuddin Sabbir
}

\section{Abstract}

Purpose- The purpose of this paper is to investigate the factors affecting customer intention to purchase life insurance.

Design/Methodology/Approach- Based on a sample of 200 individuals, this study is basically descriptive in nature and used both primary and secondary sources of data. To investigate the relationship between dependent and independent variables one way ANOVA tests, Correlation and Multiple Regression Analysis were conducted throughout the research.

Findings- The paper demonstrates that socio-demographic variables except occupation have no significant influence on purchase intentions for life insurance. The study also demonstrated that bequest motive and financial literacy had the most significant impact on customer purchase intention for life insurance. However, precautionary motive was found to be insignificant in influencing customer interest or intention to purchase Life insurance.

Research Limitations- The major limitations of this paper is the small sample size. Additionally, future studies may incorporate some other variables such as religiosity and national culture which were not considered in this study.

Practical implications- The paper will be helpful for marketer to gain a better understanding of customer and the factors that make them interested or intended to purchase life insurance in Bangladesh.

Originality- It is apparent that there are very few studies that focused on several determinants of life insurance demand and indeed none of them incorporated collectively the factors considered in this study for predicting customer purchase intention for life insurance. In this regard this paper makes significant contribution in satisfying the gap in the scope. Therefore, the authors expects that this paper will provide marketers with a clear understanding of general peoples' interest in life insurance and the cumulative impact of socio-demographic, financial literacy, saving motives and risk aversion motives on purchase intention for life insurance.

Keywords: Life insurance, Financial literacy, Saving motives, Risk aversion.

\section{Introduction}

Insurance is considered as a tool for managing risks and providing financial security (Omar and Owusu, 2007). Human life is regarded as the most precious asset in the earth and life insurance is to be considered as one kind of measure to provide financial protection to a person and his family at the period of uncertain dangers or any disaster such as uncertain death or accident (Chaudhary, 2016). Zakaria et al. (2016) suggested that life insurance assists individuals save money while defending against any personal risks or hazards in their life. According to Hofstede (1995), the most important task of life insurance is to protect against financial loss derived from the loss of human life. In addition to covering the risk of death, life insurance also covers the risks of disability, critical illness, and superannuation (Nekmahmud, Shahedul and Ferdush, 2017). Therefore, life insurance is considered as a mean for people to ensure a constant flow of income to the beneficiaries (Todd, 2004). Chaudhary (2016), expressed that life insurance is needed in order to meet family's financial requirements, make repayments of loans and expenses, encourage diverse investment options, get support in case of illnesses and accidents, get tax benefits, draw loans against insurance. Therefore, life insurance plays a vital role in encouraging savings, financial investment, and risk management (Nekmahmud, Shahedul and Ferdush, 2017).

\footnotetext{
${ }^{1}$ Lecturer, Department of Marketing, University of Barisal, E-mail: tjahan@bu.ac.bd

${ }^{2}$ Assistant Professor, Department of Marketing, University of Barisal, E-mail: mmsabbir@bu.ac.bd
} 
Business Review- A Journal of Business Administration Discipline, Khulna University, Volume: 13, Number: 1E2,January-December 2018, pp.13-28 (Print ISSN : 1811-3788; Online ISSN : 2664-3502)

The history of insurance industry of Bangladesh dated back to British Era. But this industry actually gained its impetus from 1947 to 1971. After the liberation war in 1971 the government of Bangladesh formed Bangladesh Insurance (Nationalization) Order 1972 and nationalized all the life and non-life insurance companies by placing all insurance companies (except postal life insurance and foreign life insurance companies) under five public corporations. On 14 May 1973 under the Insurance Corporations Act 1973, government restructured five public corporations into two public corporations namely: "Sadharan Bima Corporation (SBC)" for general business and "Jiban Bima Corporation (JBC)" for life business. In 1984, insurance companies have permitted in the private sector alongside nationalized insurance companies (Mamun, 2013; Ahmed, 2016).Right now, apart from one public life insurance company there are thirty private life insurance companies in Bangladesh (BIA, 2018).

Despite its huge market potential, the life insurance industry is suffering from several problems from both industry and policy holders' end. Lack of risk awareness, low purchasing power, higher degree of risk in the market and lack of spontaneity from company are some barriers that hold back its desired growth (Khan and Uddin, 2013).Alongside much human resource management, operational and ethical problems, life insurance has also ripened with marketing problems. Though some private life insurance companies are trying to reduce the existing fallacies among the clients about life insurance, nationalized company is still devoid of innovations and competencies in their propositions (Ahmed, 2016). Overcoming these problems and developing a comprehensive, innovative and competitive promotional campaign for life insurance require a proper understanding of target customer. But little attention has been drawn on this aspect in previous literatures in Bangladesh perspective. Several existing literatures focused on the problems, prospects and policy implications of insurance business (Mamun, 2013; Khan and Uddin, 2013) ethical standards in life insurance companies (Mamun, 2013) and customer perceptions toward insurance companies (Chowdhury, Rahman and Afza, 2007).

Therefore, to have a better understanding of customer and provide the insurance marketer with a tool for tapping customers' mind this study investigated the underlying factors that accelerate the intention to purchase life insurance. The major purpose of the study is to investigate whether demographics, financial literacy, saving motives and risk aversion motives sufficiently predict customer intentions to purchase life insurance in Bangladesh. In line with this objective, the study is also set out to achieve other specific objectives like:

a) To investigate whether there is significant relation between purchase intention and demographics, financial literacy, saving motives \& risk aversion motives.

b) To investigate the strength of relationship of demographics, financial literacy, saving motives and risk aversion motives with purchase intention.

\section{Literature Review}

Ray and Ali (2008) revealed that buying life insurance has now a day's become an attractive alternative for investment covering a number of life related risks and necessities after the retirement of policyholders. Life insurance aimed at ensuring the monetary security of family members, providing supports to the dependents, and also in meeting the outstanding financial obligation or debt after the death of policyholder (Zakaria et al., 2016). In recent years, the role of life insurance has become ever more significant as life insurance has become a crucial part of human life. In face of rapid urbanization, mobility of the population and enhancement of economic relationships between individuals, families as well as communities, life insurance undertakes a more significant role as a medium for individuals and families to manage their financial risk (Beck and Webb, 2003). Moreover, life insurance plays a crucial role in boosting up the national savings as well as smoothing the paths of economic developments of a country (Nekmahmud, Shahedul and Ferdush, 2017).

Comprehending these pivotal roles of life insurance, marketers need to come up with better propositions for customers. In doing so, a better knowledge about factors affecting customer intentions to purchase life insurance will come handy in time. Previously several researchers worked with factors affecting customer intentions to purchase life insurance. Zakaria et al. (2016) identified three factors namely financial literacy, saving motives and religiosity as factors that affect intentions to purchase Islamic life insurance. In this regard, Mahdzan and Victorian (2013) suggested three determinants called demographics, financial literacy and saving motives. On the other hand, Curak, Dzaja, \& Pepur (2013) investigated only the impacts of social and demographic factors on life insurance 
Business Review- A Journal of Business Administration Discipline, Khulna University, Volume: 13, Number: 1E2,January-December 2018, pp.13-28 (Print ISSN : 1811-3788; Online ISSN : 2664-3502)

demand. Yazid et al. (2012) also added some economic and socio-economic determinants for Islamic life insurance demand. In this study authors' investigated the factors namely socio-demographics, financial literacy, saving motives and risk aversion motives for predicting intentions to purchase life insurance. To the best of authors' knowledge no research has investigated these factors collectively to predict intentions to purchase life insurance.

\section{Socio-Demographic variables:}

Age: The life insurance purchase decision varies significantly depending on the different age groups of individuals. Ando and Modigliani (1963) posited that individuals usually plan their saving behavior over the long-term. As income differs depending on the different life cycle stages of individual, saving varies over the age of individual. According to Curak, Dzaja and Pepur (2013), the demand for life insurance is lined up with the life-cycle theory because of income variability during the lifetime of an individual. A possible reason is that increase in age leads to a higher positive attitude toward insurance and people who are leading towards the end of an active life are more likely to aware of after retirement life (Yusof, Gbadamosi and Hamadu, 2009).

Gender: Gandolfi and Miners (1996) examined the influence of gender on purchase or consumption of life insurance. It can be generally said that demand for life insurance may differ among men and women depending on the different stages in lifetime. The assumption is that the insurance demand increases along with the probability of death and individuals having high probability of death are more likely to purchase insurance. As men live shorter than women, they will demand insurance more. But Curak, Dzaja, andPepur (2013) didn't find any significant relationship between gender and life insurance demand and concluded differently that men and women equally demand life insurance.

Marital Status: Mantis and Farmer (1968) proposed that marriage have influence on life insurance demand as married men want to provide protection to their dependents in case of death of breadwinner, thus spend more money for life insurance compared to single men. But empirical results showed that unmarried individuals have more disposable income and less financial commitments than married ones and hence, they can afford to buy life insurance more compared to married individuals who have to spend more on supporting their families. Mahdzan and Victorian (2013) concluded that life insurance is mostly purchased by single individuals, followed by married individuals and is least bought by individuals who are divorced. A probable reason is that single men may not have anyone on whom he can depend on in case of a major health crisis such as disability and hence, they have to depend on life insurance policies.

Number of Dependents: Individuals with children have a stronger propensity to leave bequeath able wealth in the form of life insurance. Protection of the dependent members of family against financial suffering in the event of a breadwinner's premature death is an important reason of buying life insurance. Usually it is assumed that households with fewer family members tend to buy life insurance because they have more income available compared to households with more family members who spend most of their income for dependents. Nevertheless, there is an opposite effect -the increasing number of dependents indicates that the individuals need to buy more life insurance for the protection of their large number of dependent members (Chui and Kwok, 2011).

Education: Education is assumed to have positive influence on the purchase of life insurance. Truett and Truett (1990) suggested that people having higher education usually tend to a have strong desire and awareness to safeguard their dependents against risk while maintaining their standard of living. Browne and Kim (1993) explicated that higher level of education results in greater awareness of uncertainties in individual's life, hence leading to higher life insurance coverage. Higher education helps household develop a positive attitude toward life insurance (Yusuf, Gbadamosi and Hamadu, 2009) and a greater awareness which leads to an increase in the understanding of the importance of life insurance (Hammond, Houston and Melander, 1967; Brown and Kim, 1993; Hwang and Gao, 2003; Savvides, 2006; Nesterova, 2008; Curakand Gaspic, 2011).

Occupation: The employment status of an individual has significant impact on the life insurance purchasing decision (Black and Skipper, 1993). This is because employed individuals have a continuous flow of income and have funds to buy life insurance (Curak, Dzaja and Pepur, 2013). Hammond, Houston and Melander (1967) and 
Business Review- A Journal of Business Administration Discipline, Khulna University, Volume: 13, Number: 1E2,January-December 2018, pp.13-28 (Print ISSN : 1811-3788; Online ISSN : 2664-3502)

Mantis and Farmer (1968) found influence of employment on life insurance consumption. Hence, life insurance will be demanded more by individuals who are employed compared to the unemployed individuals.

Income: Delafrooz and Paim (2011) found that individuals having higher incomes are more likely to involve in financial management behaviors, such as saving money or investing in various savings channels. All theories related to income and savings growth rate suggested that an increase in income results in an increase in investment rate (Raza, Farhan and Akram, 2011). Mahdzan and Victorian (2013) in their study found that income is positively related to the life insurance demand. As income of an individual steps forward to higher levels, substitutes for individual life insurance become available (Hammond, Houston and Melander, 1967) and as income increases, life insurance becomes reasonably more affordable (Brown and Kim, 1993).

\section{Financial Literacy}

Financial literacy refers to the ability of individual stoplan their finances efficiently through proper utilization of savings toamass wealth, effective conservation of such wealth against value depreciation and losses and finally, proper distribution of wealth at the later stage of life (Mahdzan and Victorian, 2013). Financial literacy can simply be defined as the knowledge of effectively making any form of decisions that may have influence on an individual's finance, such as real estate, investing and saving, insurance, and retirement, etc. It also involves an individual's knowledge or awareness of financial concepts, financial planning and so more. Life insurance policy is regarded as one of the crucial components of an individual's financial plan (Zakaria et al., 2016). Generally, it is assumed that people who are highly financially literate are more likely to be engaged in financial planning such as investing in unit trust, home financing and life insurance purchasing, compared topeople who have lower levels of financial literacy (Mahdzan and Victorian, 2013). Lusardi, Mitchell and Curto (2010) concluded that financial literacy is imperative for making sound financial decision as individuals who have lower level of financial literacy are less likely to build upwealth, and make plan for their retirement. Financial literacy improves the ability of a person regarding how to handle day to day financial affairs and will lessen the negative effects of poor financial decisions that might otherwise take years to overcome (Delafrooz and Paim, 2011). Shafii, Abiddinand Ahmad (2009)concluded that higher level of financial literacy results in higher involvement of individuals in financial planning actions including investment in shares, property and life insurance. Delafrooz and Paim (2011) found that financial literacy playsa vital role in explaining attitudes toward saving and it continues to be a significant determinant of financial planning. Financial illiteracy significantly affects the ability to save and to secure a comfortable retirement. Mahdzan and Victorian (2013) posited that financial literacy was expected to have a significant impact on demand for life insurance, as more knowledge and information on financial affairs will enable persons to make more substantive financial plans as well as more well-versed decisions regarding proper distribution of money and savings. But Mahdzan and Victorian (2013) in their study found that financial literacy had no direct impact on demand for life insurance and suggested that regardless of whether or not people are financially literate, they could still be sensitive to uncertainties in their life and demand for life insurance.

\section{Saving Motives}

Life insurance provides both safety and protection to individuals and also boost up savings among people (Chaudhary, 2016). Mimović, Jakšić and Todorović (2017) stated that new innovations in life insurance offer long term saving and investment opportunities for people because insurance companies now a day's offer endowment and investment-linked type of policies that help to meet accumulation purpose. Saving motives is characterized by several main aspects of savings. However, according to several scholars, there are four established aspects of saving motives-Precautionary motives (Hubbard, Skinner and Zeldes, 1995), Life cycle motives (Modigliani and Brumberg, 1954; Liebenberg, Carson, and Dumm, 2012), Bequest motives (Bernheim, Shleifer and Summers, 1985) and Wealth accumulation motives or Profit motives (Mahdzan and Victorian, 2013; Canova, Rattazzi and Webley, 2005).According to Mahdzan and Victorian (2013), these four motives significantly influence the life insurance demand. Wealth accumulation motive has the strongest impact on life insurance demand, followed by bequest motives, life cycle motives, and precautionary motives (Mahdzan and Victorian, 2013).

Precautionary Motive : Precautionary motive can be defined as the efforts undertaken by individuals in an attempt to lessen the uncertainties in life (Mahdzan and Victorian, 2013). Hofstede (1995)stated that the main purpose of life 
Business Review- A Journal of Business Administration Discipline, Khulna University, Volume: 13, Number: 1E2,January-December 2018, pp.13-28 (Print ISSN : 1811-3788; Online ISSN : 2664-3502)

insurance is to protect against financial loss derived from the loss of human life. Todd (2004) stated that life insurance put back a lost stream of income that results from the death of an individual. Abel (1985) mentioned that a precautionary demand for saving takes place because for an individual consumer it is not possible to know in advance the date at which he will die and that's why he will like to purchase life insurance as a precaution for the use of future consumption. Mahdzan and Victorian (2013) asserted that the demand for life insurance is significantly influenced by precautionary motives, as life insurance defend against personal risks of life, health and disability.

Life Cycle Motive: Life cycle motive has a positive impact on the demand for Life insurance, as individuals with life cycle motive are highly likely to invest in some form of saving at present with a view to ensuring financial safety in the future to face any life cycle event such as meeting expenditures for wedding, a new born, education or burial expenses (Mahdzan and Victorian, 2013). Modigliani and Brumberg (1954) asserted that individuals are likely to smooth out their consumption and save money to meet the expenses of major life cycle events that may occur later in life, such as education, purchase of a house, wedding, or for having a child. In this regard, Liebenberg, Carson and Dumm, (2012) asserted that purchase of life insurance tends to follow various life events such as marriage, the birth of a child, purchasing a house and getting a new job; similarly termination of life insurance tends to follow some other life events such as death of a spouse, divorce, unemployment and retirement. Modigliani and Brumberg (1954) found that households tend to accumulate their wealth by saving during their working years or high income period in order to use these saving sat the time of retirement.

Bequest Motive: Life insurance serves as a mechanism for individuals to ensure a constant flow of income to their beneficiaries. Mahdzan and Victorian (2013)asserted that Bequest motive is a strong determinant of life insurance demand and significantly influence the demand for life insurance as individuals with bequest motives are likely to think about leaving an inheritance for their beloved ones in the event of their death. According to Bernheim, Shleifer and summers (1985), Bequest motive refers to the intention of leaving an inheritance to the next of kin or dependents. Conventionally, life insurance was purchased in an attempt to depart certain amount of money for the beneficiaries so that they will be able to pay for burial expenses of the deceased such as insured (Mahdzan and Victorian, 2013). Avery and Kennickell (1991) found that elderly households did not spend much of their wealth because of uncertainty with respect to life expectancy or to bequest motives. A strong motive for saving amongst U.S. households is the bequest motive (Bernheim, 1991). Fitzgerald (1987) asserted that life insurance purchases are likely to depend on how well off a couple chooses to leave the survivors if both members had lived.

Wealth Accumulation Motive: Life insurance is regarded as a means of disciplined contractual saving and a major source of long term accumulation of finances (Beckand Webb, 2003). Mahdzan and Victorian (2013)found that wealth accumulation motive has the strongest impact on the life insurance demand and individuals with wealth accumulation motives are more likely to have a higher demand for life insurance as they consider life insurance as a form of savings and are willing to accumulate funds for future use. Wärneryd (1999) concluded that individuals generally save to accumulate capital, or in other words, to make a 'profit' from their savings. Households want to accumulate more wealth when they are faced with greater uncertainty for instance the potential fluctuations in future income and sudden out-of-pocket medical expenses and thus increasing the demand for life insurance (Diacon and Mahdzan, 2008).

\section{Risk Aversion Motives}

Consumers may differ with regard to the amount of risk they want to incur in a given situation (Mandrik and Bao, 2005). Different people will respond to similar risky situations in very different ways (Outreville, 2014). This basic attitude of an individual toward risk is called risk aversion, a concept that has received much research attention not only in Marketing, but also in Economics and Finance (Matzler, Krauter and Bidmon, 2008).Generally, the notion of risk consists of two components: the uncertainty of an outcome and the significance of negative consequences related with the outcome of an action (Rousseau et al., 1998). Differences in the individuals' behavior derived from facing similar risky situations could be explained to some extent by the individual's family background, education, occupation, status, prior experience, and geographical location (Kogan and Wallach, 1964). The traditional anthropological theory stated that culture guides an individual regarding their choice between risk-avoiding and risk accepting strategies (Ward and Zurbruegg, 2000).A risk averse individual always prefers less risk to more risk 
Business Review- A Journal of Business Administration Discipline, Khulna University, Volume: 13, Number: 1E2,January-December 2018, pp.13-28 (Print ISSN : 1811-3788; Online ISSN : 2664-3502)

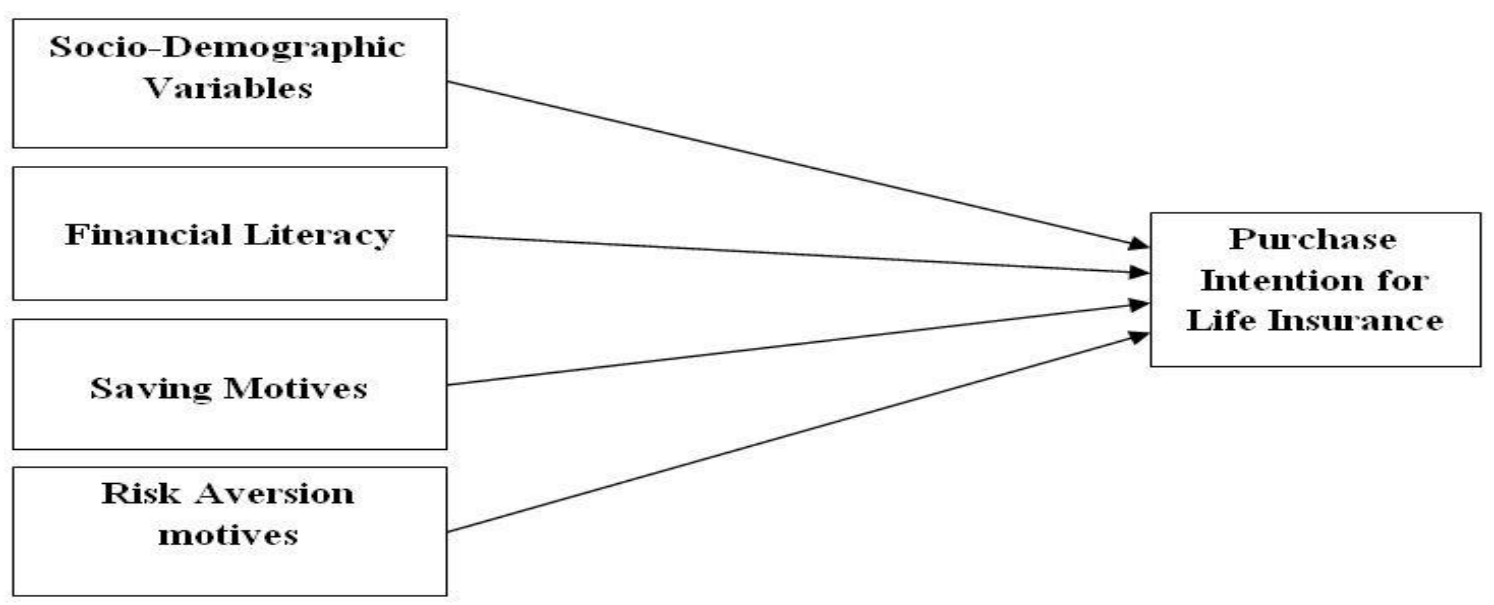

Figure 1: Conceptual Model developed by the authors for the current study purpose based on literature reviews.

(Outreville, 1998). From the literature on the demand for insurance it is derived that the relative risk aversion of individuals and the wealth elasticity of insurable risky wealth are the key determinants of changes in the willingness to insure (Raviv, 1979; Doherty and Schlesinger, 1983; Chesney and Loubergé,1986). Karni and Zilcha (1986) addressed the problem regarding the measurement of risk aversion and studied the implications of differences in risk aversion for the most favorable choice of life insurance coverage. Cleeton and Zellner (1993) showed the relationship between insurance demand and income considering the change in the degree of risk aversion. At a macro-economic level, it has been concluded by Szpiro (1986) that it is feasible to acquire an aggregate measure of risk aversion through the observation of the individual's behavior towards the demand for insurance. In this regard, Greene (1963) found no significant association between risk attitudes and previous insurance purchasing behavior.

Conceptual Framework Based on the discussions of literature review section following hypotheses have been developed that are to be tested and a proposed research framework has been illustrated afterward:

Hypothesis 1: Demographic profiles have significant influence on purchase intention for life insurance.

Hla: Age has significant influence on purchase intention for life insurance.

$H 1 b$ : Gender has significant influence on purchase intention for life insurance.

H1c: Marital Status has significant influence on purchase intention for life insurance.

HId: Number of dependents has significant influence on life insurance purchase.

Hle: Education has significant influence on purchase intention for life insurance.

HIf: occupation has significant influence on purchase intention for life insurance.

Hlg: Income has significant influence on purchase intention for life insurance.

Hypothesis 2: Financial Literacy has significant and positive influence on purchase intention for life insurance.

Hypothesis 3: Saving Motives has significant and positive influence on purchase intention for life insurance.

H3a: Precautionary Motive has significant and positive influence on purchase intention for life insurance.

$H 3 b$ : Life Cycle Motive has significant and positive influence on purchase intention for life insurance.

$H 3 c$ : Bequest Motive has significant and positive influence on purchase intention for life insurance.

H3d: Wealth accumulation Motive has significant and positive influence on purchase intention for life insurance.

Hypothesis 4: Risk Aversion has significant and positive influence on purchase intention for life insurance.

\section{Methodology}

Research Design: For this study, conclusive research design has been used as it is more structured and obtained data are analyzed quantitatively (Malhotra, 2010). As this study investigates whether demographics, financial literacy, saving motives and risk aversion motives sufficiently predict customer intentions to purchase life insurance in 
Business Review- A Journal of Business Administration Discipline, Khulna University, Volume: 13, Number: 1E2,January-December 2018, pp.13-28 (Print ISSN : 1811-3788; Online ISSN : 2664-3502)

Bangladesh, descriptive research design is suitable and data has been gathered only once from a group of respondents so it is a part of single cross sectional research design.

Measurement and Scaling: All the dependent and independent variables except demographic variables has been measured using a Likert type scale, ranging from 1 to 5 (1=Strongly agree, 2=Agree, 3=Neutral, 4=Disagree, $5=$ Strongly disagree) as suggested by Mahdzan \& Victorian (2013).

Sampling Method: As the research aimed to investigate the factors accelerating life insurance purchase amongst people who already have or are eligible to purchase a life insurance plan, a non-probability purposive sampling method has employed to select a sample size. This method was previously employed by Mahdzan and Victorian (2013) for the same category of research. Samples have been drawn from Dhaka and Barishal, two major cities of Bangladesh. Zakaria et al. (2016) asserted that a sample size ranges from 30 to 500 is sufficient for this type of the research. In their research, Zakaria et al. (2016) used a sample size of 200 whereas Mahdzan and Victorian (2013) used 259 samples. In this study authors' used a sample size of 200 which corresponds with previous studies.

Data Collection and Analysis: Both the primary and secondary data have been collected for the research purpose. Primary data were collected using questionnaire survey because it is very handy, suitable and allow the researchers to cover different locations in shorter time (Zakaria et al., 2016). Secondary data were collected from published books, journals, research papers, theses etc. Different types of analyses using SPSSv20 were conducted in the research. Firstly, descriptive analyses were conducted for demographic variables. Secondly, one way ANOVA tests were carried out to test hypotheses from H1a to H1g. This is because here independent variables (demographic variables) were categorical in nature and dependent variables (purchase intention) were continuous in nature (Mahdzanand Victorian, 2013; Rha, Mont alto and Hanna, 2006). Third, pear son correlation was used to identify the correlation between various independent and dependent variables as suggested by Zakaria et al. (2016). Finally, multiple regression analysis was employed on dependent variables, regressed on six independent variables which are congruent with previous studies (Zakaria et al., 2016; Mahdzan and Victorian, 2013).

Instrument and Measures: Self-administered questionnaire was the main instrument, exercised for data collection. Measures for socio-demographic variables were adopted from several studies (Rha, Montalto and Hanna, 2006; Dragos, 2014; Mahdzan and Victorian, 2013; Delafrooz and Paim, 2011). Four items were adopted from Mahdzanand Victorian (2013) and one from Hassan (2014) to measure Financial literacy. All the indicators for Lifecycle motives, Precautionary motives, Bequest motives, Wealth accumulation motives were adopted from Mahdzan and Victorian (2013). Items for Risk aversion motives were imported and adopted from Schooled and Worden (1996). Finally, three items were developed by the researchers to measure customer intentions to purchase life insurance.

\section{Analysis and Results}

Descriptive Analysis: Table 1 describes the demographic profile of the respondents.

Table 1: Demographic Profile of the Respondents

\begin{tabular}{|l|l|c|c|}
\hline & & Frequency & Valid Percentage \\
\hline \multirow{4}{*}{ Age } & Under 35 & 127 & 63.5 \\
\cline { 2 - 4 } & 35 up to 45 & 36 & 18.0 \\
\cline { 2 - 4 } & 45 up to 55 & 24 & 12.0 \\
\cline { 2 - 4 } & 55 up to 65 & 7 & 3.5 \\
\cline { 2 - 4 } & Above 65 & 6 & 3.0 \\
\cline { 2 - 4 } & Total & 200 & 100.0 \\
\hline \multirow{5}{*}{ Profession } & Businessman & 13 & 6.5 \\
\cline { 2 - 4 } & Job Holder & 133 & 66.5 \\
\cline { 2 - 4 } & Student & 31 & 15.5 \\
\cline { 2 - 4 } & Housewife & 15 & 7.5 \\
\hline
\end{tabular}


Business Review- A Journal of Business Administration Discipline, Khulna University, Volume: 13, Number: 1E2,January-December 2018, pp.13-28 (Print ISSN : 1811-3788; Online ISSN : 2664-3502)

\begin{tabular}{|c|c|c|c|}
\hline & Others & 8 & 4.0 \\
\hline & Total & 200 & 100.0 \\
\hline \multirow[t]{6}{*}{ Income } & $<10,000$ & 51 & 25.5 \\
\hline & $10,000-24,999$ & 31 & 15.5 \\
\hline & $25,000-49,999$ & 84 & 42.0 \\
\hline & $50,000-99,999$ & 30 & 15.0 \\
\hline & $>1,00,000$ & 4 & 2.0 \\
\hline & Total & 200 & 100.0 \\
\hline \multirow[t]{6}{*}{ Education } & SSC & 7 & 3.5 \\
\hline & $\mathrm{HSC}$ & 15 & 7.5 \\
\hline & Graduate & 66 & 33.0 \\
\hline & Post Graduate & 103 & 51.5 \\
\hline & Above Post Graduate & 9 & 4.5 \\
\hline & Total & 200 & 100.0 \\
\hline \multirow[t]{3}{*}{ Gender } & Female & 51 & 25.5 \\
\hline & Male & 149 & 74.5 \\
\hline & Total & 200 & 100.0 \\
\hline \multirow[t]{4}{*}{ Marital Status } & Single & 87 & 43.5 \\
\hline & Married & 108 & 54.0 \\
\hline & Divorced & 5 & 2.5 \\
\hline & Total & 200 & 100.0 \\
\hline \multirow{5}{*}{$\begin{array}{l}\text { Number of } \\
\text { Dependents }\end{array}$} & None & 79 & 39.5 \\
\hline & 1 & 34 & 17.0 \\
\hline & 2 & 44 & 22.0 \\
\hline & 3 & 43 & 21.5 \\
\hline & Total & 200 & 100.0 \\
\hline
\end{tabular}

(Source: Authors' Calculations)

Analysis based on Demographic Information: One-way ANOVA: One way ANOVA tests were conducted for socio-demographic variables as they are categorical in nature. One-way ANOVA with respect to Age: Results from Table 2 suggest that purchase intentions for life insurance among different age groups are almost same. Besides, ANOVA test $(F=1.594$, Sig $=.177)$ indicates there are no significant differences between age groups and purchase intention for life insurance. Therefore, H1a isn't accepted.

Table 2: One Way ANOVA: Age and Purchase Intention for Life Insurance

\begin{tabular}{|c|c|c|c|}
\hline Age & Mean & N & Std. Deviation \\
\hline Under 35 & 3.6352 & 127 & .80281 \\
\hline 35 up to 45 & 3.6667 & 36 & .91894 \\
\hline 45 up to 55 & 3.8889 & 24 & .79044 \\
\hline 55 up to 65 & 3.1429 & 7 & .99735 \\
\hline Above 65 & 4.1111 & 6 & .88611 \\
\hline Total & 3.6683 & 200 & .83709 \\
\hline
\end{tabular}

DV: PI, F= 1.594, Sig=.177

(Source: Authors' Calculations)

One-way ANOVA with respect to Gender: Results from Table 3 suggest that purchase intentions for life insurance among different gender groups are not much different. Besides, ANOVA test $(F=.481$, Sig $=.489)$ indicates there are no significant differences between gender groups and purchase intention for life insurance. Therefore, H1b isn't accepted. 
Business Review- A Journal of Business Administration Discipline, Khulna University, Volume: 13, Number: 1E2,January-December 2018, pp.13-28 (Print ISSN : 1811-3788; Online ISSN : 2664-3502)

Table 3: One Way ANOVA: Gender and Purchase Intention for Life Insurance

\begin{tabular}{|c|c|c|c|}
\hline Gender & Mean & $\mathrm{N}$ & Std. Deviation \\
\hline Female & 3.7386 & 51 & .87003 \\
\hline Male & 3.6443 & 149 & .82715 \\
\hline Total & 3.6683 & 200 & .83709 \\
\hline
\end{tabular}

DV: PI, F= .481, Sig=.489

(Source: Authors' Calculations)

One-way ANOVA with respect to Marital Status: Though results (Table 4) suggest that purchase intentions for life insurance among divorced respondents are high, but they are few in numbers. Besides, ANOVA test $(F=2.810$, Sig $=.063)$ indicates there are no significant differences between marital status groups and purchase intention for life insurance. Therefore, H1c isn’t accepted.

Table 4: One Way ANOVA: Marital Status and Purchase Intention for Life Insurance

\begin{tabular}{|c|c|c|c|}
\hline Marital Status & Mean & $\mathrm{N}$ & Std. Deviation \\
\hline Single & 3.6322 & 87 & .83532 \\
\hline Married & 3.6574 & 108 & .83841 \\
\hline Divorced & 4.5333 & 5 & .29814 \\
\hline Total & 3.6683 & 200 & .83709 \\
\hline
\end{tabular}

DV: PI, F= 2.810, Sig=.063

(Source: Authors' Calculations)

One-way ANOVA with respect to Number of Dependents: According to Table 5, ANOVA test $(F=.499$, Sig=.684) indicates there are no significant differences between number of dependents groups and purchase intention for life insurance. Therefore, H1d isn't accepted.

Table 5: Number of Dependents and Purchase Intention for Life Insurance

\begin{tabular}{|c|c|c|c|}
\hline Number of Dependents & Mean & N & Std. Deviation \\
\hline None & 3.6498 & 79 & .84209 \\
\hline 1 & 3.5784 & 34 & .87351 \\
\hline 2 & 3.6439 & 44 & .82718 \\
\hline 3 & 3.7984 & 43 & .82340 \\
\hline Total & 3.6683 & 200 & .83709 \\
\hline
\end{tabular}

DV: PI, F= .499, Sig=.684

(Source: Authors' Calculations)

One-way ANOVA with respect to Education: According to Table 5, ANOVA test $(F=1.950$, Sig $=.104)$ indicates there are no significant differences between education groups and purchase intention for life insurance. Therefore, H1e isn't accepted.

Table 6: Education and Purchase Intention for Life Insurance

\begin{tabular}{|c|c|c|c|}
\hline Education & Mean & N & Std. Deviation \\
\hline SSC & 4.2381 & 7 & .62994 \\
\hline HSC & 3.4889 & 15 & 1.00685 \\
\hline Graduate & 3.6919 & 66 & .85197 \\
\hline Post Graduate & 3.5987 & 103 & .80624 \\
\hline Above Post Graduate & 4.1481 & 9 & .70929 \\
\hline Total & 3.6683 & 200 & .83709 \\
\hline
\end{tabular}

DV: PI, F= 1.950, Sig=.104

(Source: Authors' Calculations) 
Business Review- A Journal of Business Administration Discipline, Khulna University, Volume: 13, Number: 1E2,January-December 2018, pp.13-28 (Print ISSN : 1811-3788; Online ISSN : 2664-3502)

One-way ANOVA with respect to Occupation: According to Table 5, ANOVA test $(F=2.566$, Sig $=.040)$ indicates there are significant differences between occupation groups and purchase intention for life insurance. Therefore, H1f is accepted. So, it can be inferred that occupation has significant impact on purchase intention for life insurance.

Table 7: Occupation and Purchase Intention for Life Insurance

\begin{tabular}{|c|c|c|c|}
\hline Occupation & Mean & $\mathrm{N}$ & Std. Deviation \\
\hline Businessman & 4.0513 & 13 & 1.04391 \\
\hline Job Holder & 3.6692 & 133 & .81288 \\
\hline Student & 3.4839 & 31 & .71408 \\
\hline Housewife & 4.0000 & 15 & .00000 \\
\hline Others & 3.1250 & 8 & .64087 \\
\hline Total & 3.6683 & 200 & .83709 \\
\hline
\end{tabular}

DV: PI, F= 2.566, Sig=.040

(Source: Authors' Calculations)

One-way ANOVA with respect to Monthly Income: According to Table 5, ANOVA test $(F=.818$, Sig $=.515)$ indicates there are no significant differences between monthly income groups and purchase intention for life insurance. Therefore, H1g isn't accepted.

Table 8: Monthly Income and Purchase Intention for Life Insurance

\begin{tabular}{|c|c|c|c|}
\hline Monthly Income & Mean & $\mathrm{N}$ & Std. Deviation \\
\hline$<10,000$ & 3.5752 & 51 & .85135 \\
\hline $10,000-24,999$ & 3.5484 & 31 & .72800 \\
\hline $25,000-49,999$ & 3.6905 & 84 & .84832 \\
\hline $50,000-99,999$ & 3.8444 & 30 & .90437 \\
\hline$>1,00,000$ & 4.0000 & 4 & .72008 \\
\hline Total & 3.6683 & 200 & .83709 \\
\hline
\end{tabular}

DV: PI, F= .818, Sig=.515

(Source: Authors' Calculations)

Correlation Analysis: Correlation between the dependent and independent variables was calculated using Pearson Correlation analysis (Table 9).

Table 9: Correlations between Variables

\begin{tabular}{|l|l|l|l|l|l|l|l|}
\hline & $F L$ & $L C M$ & $P M$ & $B M$ & WAM & RAM & PI \\
\hline$F L$ & 1 & & & & & & \\
\hline$L C M$ & $.482^{* *}$ & 1 & & & & & \\
\hline$P M$ & $.421^{* *}$ & $.694^{* *}$ & 1 & & & & \\
\hline$B M$ & $.278^{* *}$ & $.630^{* *}$ & $.594^{* *}$ & 1 & & & \\
\hline$W A M$ & $.300^{* *}$ & $.531^{* *}$ & $.589^{* *}$ & $.541^{* *}$ & 1 & & \\
\hline$R A M$ & .003 & -.097 & -.120 & -.079 & .001 & 1 & \\
\hline$P I$ & $.493^{* *}$ & $.613^{* *}$ & $.569^{* *}$ & $.583^{* *}$ & $.537^{* *}$ & .060 & 1 \\
\hline
\end{tabular}

(Source: Authors' Calculations)

Table 9 represents positive correlations between purchase intentions for life insurance and all the independent variables namely financial literacy, life cycle motives, precautionary motives, bequest motives, wealth accumulation motives, risk aversion motives. Among the independent variables life cycle motives show highest positive correlation $(\mathrm{r}=.613, \mathrm{p}=.000)$ with purchase intention which is subsequently followed by bequest motives $(\mathrm{r}=.583$, $\mathrm{p}=.000)$, precautionary motives $(\mathrm{r}=.569, \mathrm{p}=.000)$, wealth accumulation motives $(\mathrm{r}=.537, \mathrm{p}=.000)$, financial literacy $(\mathrm{r}=.493, \mathrm{p}=.000)$ and risk aversion motives $(\mathrm{r}=.060, \mathrm{p}=.000)$. 
Business Review- A Journal of Business Administration Discipline, Khulna University, Volume: 13, Number: 1E2,January-December 2018, pp.13-28 (Print ISSN : 1811-3788; Online ISSN : 2664-3502)

Multiple Regression Analysis: Multiple regression analysis was conducted to investigate whether financial literacy, life cycle motives, precautionary motives, bequest motives, wealth accumulation motives and risk aversion motives sufficiently predict purchase intentions for life insurance.

Table 10: Purchase Intentions for Life Insurance

\begin{tabular}{|c|c|c|c|c|c|}
\hline \multirow[t]{2}{*}{ Variables } & \multicolumn{2}{|c|}{ Unstandardized Coefficients } & \multirow{2}{*}{$\begin{array}{c}\text { Standardized Coefficients } \\
\text { Beta }\end{array}$} & \multirow{2}{*}{$\mathrm{t}$} & \multirow{2}{*}{ Sig. } \\
\hline & $\mathrm{B}$ & Std. Error & & & \\
\hline (Constant) & .007 & .319 & & .022 & .982 \\
\hline FL & .271 & .065 & .238 & 4.193 & .000 \\
\hline LCM & .175 & .071 & .191 & 2.460 & .015 \\
\hline PM & .096 & .074 & .098 & 1.294 & .197 \\
\hline $\mathrm{BM}$ & .216 & .057 & .257 & 3.776 & .000 \\
\hline WAM & .164 & .063 & .168 & 2.612 & .010 \\
\hline RAM & .128 & .058 & .109 & 2.198 & .029 \\
\hline
\end{tabular}

a. **Correlation is significant at the 0.05 level.

b. Dependent variable: PI.

c. Predictors: FL, LCM, PM, BM, WAM, RAM.

d. ANOVA: $F=37.176$, sig $=.000$

e. Model summary: $\mathbb{R}=.732, \mathbb{R}^{2}=.536$, Adjusted $\mathbb{R}^{2}=.522$

\section{(Source: Authors' Calculations)}

Table 10 reveals that Adj. $R^{2}$ is $0.522(F=37.176, p=0.000)$ which indicates that the independent variables explain quite a considerable portion of the variance in the dependent variable. Notably, all independent variables have positive impact on dependent variable and except for precautionary motives (PM) the results are also statistically significant. Hence, $\mathrm{H} 2, \mathrm{H} 3 \mathrm{~b}, \mathrm{H} 3 \mathrm{c}, \mathrm{H} 3 \mathrm{~d}$ and $\mathrm{H} 4$ all are supported. Among the independent variables, precautionary motives (PM) has positive impact on dependent variables but this result is not statistically significant $(\beta=.098$, $p>.05)$.Therefore, $\mathrm{H} 3 \mathrm{a}$ is not supported. It can be seen that bequest motives has the highest impact $(\beta=.257, p<.05)$ subsequently followed by financial literacy $(\beta=.238, p<.05)$, life cycle motives $(\beta=.191, p<.05)$, wealth accumulation motives $(\beta=.168, p<.05)$ and risk aversion motives $(\beta=.109, p<.05)$.

\section{Discussions of Results}

Current study investigated the determinants of customer purchase intentions for life insurance. It has been found from the one way ANOVA tests that except for occupation all other socio-demographic variables have no significant impact on purchase intentions for life insurance. This finding is not congruent with previous studies (Mahdzan and Victorian, 2013; Curak, Dzaja and Pepur, 2013).This is because previous studies showed the impact of sociodemographic variables on life insurance demand which involved actual purchase of life insurance, whereas this study investigated the impact of socio-demographic variables on purchase intention for life insurance which did not involve any actual purchase of life insurance. Respondents were asked just to express their purchase intentions. Therefore, from this finding the authors' reasonably conclude that in case of purchase intentions for life insurance, socio-demographic variables are not significant predictors. This also implicates an important insight for life insurance marketer that people doesn't differ significantly in case of showing purchase interests or intentions for life insurance irrespective of different socio-demographic groups as found in current study. But when it comes to actual purchase, people behave differently based on different socio-demographic groups as found in previous studies (Mahdzan and Victorian, 2013; Curak, Dzaja and Pepur, 2013).

As for other independent variables, expectedly bequest motives has been found as the strongest predictor $(\beta=.257$, $p<.05)$ of purchase intention for life insurance. This implicates people consider life insurance as an important financial support for their heirs in absence of him or her. Life insurance marketer should highlight this aspect in their promotional campaign. Among the other saving motives, impact of life cycle motives and wealth accumulation motives on purchase intention has been found positive and significant. These findings support those of Mahdzan and Victorian (2013) and Zakaria et al. (2016). Unexpectedly, impact of precautionary motives has been found positive but not significant $(\beta=.098, p>.05)$. Though this finding contradicts that of Mahdzan and Victorian (2013), a 
Business Review- A Journal of Business Administration Discipline, Khulna University, Volume: 13, Number: 1E2,January-December 2018, pp.13-28 (Print ISSN : 1811-3788; Online ISSN : 2664-3502)

probable explanation for this is that people consider financial commitments from other sources like bank deposits for any emergency situation. Reasonably, that's why life cycle motives and wealth accumulation motives also have less influence on purchase intention than bequest motives.

Most of the insurance companies in Bangladesh set difficult terms and conditions with their policy which make it difficult for general people to understand (Mamun, 2013). This creates misconception and in many cases people lose their interest to purchase life insurance. In this regard, an important finding of this study is that financial literacy has significant and positive $(\beta=.238, p<.05)$ impact on purchase intention for life insurance. This finding is congruent with that of Zakaria et al. (2016). This finding implicates that if life insurance companies can make their terms and conditions flexible, easy to comprehend and convincible then general people will show more interest to purchase life insurance policy. Marketers should keep this in mind when devising any promotional campaign.

As for the risk aversion motives it has been found that risk aversion motives has the least positive and significant $(\beta=.109, p<.05)$ impact on purchase intention for life insurance. This implicates people with more risk avoidance intention will more likely to purchase life insurance than people with less risk avoidance intention.

\section{Limitations and Directions for Future Study}

The study encountered several limitations. Some other aspects of purchase intention could be incorporated like, religiosity and national culture. Data has been collected only from the major cities of Bangladesh which could be extended further in other rural areas of Bangladesh. Future research can incorporate more samples from different regions of Bangladesh. Though this research was restricted in Bangladesh, a cross-cultural study in this regard can add another dimension.

\section{Conclusion}

Insurance industry in Bangladesh has been a promising sector as it shows improvement in Economic, Operational, New entries and Industry growth perspective. But this sector is engulfed with many problems as identified by Mamun (2013).Besides, people have a lot misconceptions and suspicions about life insurance in Bangladesh. This study is an effort to provide some guide lines for markers to lessen few of these problems.

A well developed product or service should properly be communicated to the target customers and that's the job of a marketer. The authors' hope that alongside general insurance, life insurance will be a promising, profitable and vital contributing sector for national GDP if marketers in the life insurance business exploit the findings of this study and come up with more dynamic, competitive and contemporary policies and marketing campaigns.

\section{References}

Abel, A. B. (1985), "Precautionary saving and accidental bequests", The American Economic Review, Vol. 75, No. 4, pp. 777-791.

Ahmed, M.N.U. (2016), History of insurance industry development in Bangladesh, The New Nation. [Online] 20 th November 2016, Available from: http://thedailynewnation.com/news/114529/history-of-insurance-industrydevelopment-in bangladesh.html. [Accessed: 20th July 2018]

Ando, A. and Modigliani, F. (1963), "The life-cycle hypothesis of saving: Aggregate implications and tests", American Economic Review, Vol. 53, No.1, pp. 55-84.

Avery, R. B. and Kennickell, A. B. (1991), "Household saving in the U.S.", Review of Income and Wealth, Vol. 37, No. 4, pp. 409-432.

Bangladesh Insurance Association, (2018), Life Insurance Companies. [Online] Available from: http://biabd.com/life-insurance-companies/. [Accessed: 20th August 2018]

Beck, T. and Webb, I. (2003), "Economic, demographic and institutional determinants of life insurance consumption", The World Bank Economic Review, Vol.17, No. 1,pp. 51-88.

Bernheim, B. D. (1991), "How strong are bequest motives? Evidence based on estimates of the demand for life insurance and annuities", Journal of Political Economy, Vol. 99, No. 5, pp. 899-927.

Bernheim, B. D., Shleifer, A. and Summers, L. H. (1985), "The strategic bequest motive", Journal of Political Economy, Vol. 93, No. 6, pp. 1045-1076. 
Business Review- A Journal of Business Administration Discipline, Khulna University, Volume: 13, Number: 1E2,January-December 2018, pp.13-28 (Print ISSN : 1811-3788; Online ISSN : 2664-3502)

Black, K. j. and Skipper H.D. (2000), Life and health insurance, Prentice Hall, New Jersey.

Brown, M. J. and Kim, K. (1993), "An international analysis of life insurance demand", Journal of Risk andInsurance, Vol. 60, No. 4, pp. 616-634.

Canova, L., Rattazzi, A. M. M. and Webley, P. (2005), "The hierarchical structure of saving motives", Journal of Economic Psychology, Vol. 26, No. 1, pp. 21-34.

Chaudhary, S. (2016), "Consumer perception regarding life insurance policies: A factor analytical approach", Pacific Business Review International, Vol.9, No. 6, pp. 52-61.

Chesney, M. and Loubergé, H. (1986), "Risk aversion and the composition of wealth in the demand for full insurance coverage", SchweizerischeZeitschriftfurVolkswirtschaft und Statistic, Vol.122, No. 3, pp. 359-369.

Chowdhury, T.A., Rahman, M.I. and Afza, S.R. (2007), "Perceptions of the customers towards insurance companies in Bangladesh- A study based on the SURVQUAL model", BRAC University Journal, Vol. IV, No. 2, pp. 55-66.

Chui, A.C.W. and Kwok, C.C.Y. (2008), "National culture and life insurance consumption", Journal of International Business Studies, Vol.39, No. 1, pp. 88-101.

Cleeton, D.L. and Zellner, B.B. (1993), "Income, risk aversion and the demand for insurance", Southern Economic Journal, Vol. 60, No.1, pp. 146-156.

Curak, M. and Gaspic, K. M. (2011), "Economic and social determinants of life insurance consumption: Evidence from central and eastern europe", Journal of American Academy of Business, Vol. 16, No. 2, pp. 216-222.

Curak, M., Dzaja, I. and Pepur, S. (2013), "The effect of social and demographic factors on life insurance demand in Croatia", International Journal of Business and Social Science, Vol. 4, No. 9, pp. 65-72.

Delafrooz, N. and Paim, L. H. (2011), "Determinants of saving behaviour and financial problem among employees in Malaysia", Australian Journal of Applied and Basic Science, Vol. 5, No. 7, pp. 222-228.

Diacon, S. and Mahdzan, N. S. (2008), "Protection Insurance and Financial Wellbeing", A monograph written forthe Financial Services Research Forum, June 2008, London, UK.

Doherty, N.A. and Schlesinger, H. (1983), “Optimal Insurance in Incomplete Mar-kets", Journal of Political Economy, Vol.91, No. 6,pp.1045-1054.

Dragos, S.L. (2014), "Life and non-life insurance demand: The different effects of influence factors in emerging countries from Europe and Asia”, Economic Research-EkonomskaIstraživanja, Vol. 27, No. 1, pp. 169-180.

Fitzgerald, J. (1987), “ The effects of social security on life insurance demand by married couples”, The Journal of Risk and Insurance, Vol. 54, No. 1, pp. 86-99.

Gandolfi, A. S. and Miners, L. (1996), "Gender-Based differences in life insurance ownership", The Journal of Risk and Insurance, Vol. 63, No. 4, pp. 63-693.

Greene, M. R. (1963), "Attitudes toward risk and a theory of insurance consumption attitudes", Journal of Insurance, Vol. 30, No. 2, pp. 165-182.

Hammond, J. D., Houston, D. B. and Melander, E. R. (1967), "Household life insurance premium expenditures: an empirical approach", Journal of Risk and Insurance, Vol. 34, No. 3, pp. 397-408.

Hassan, S. H. (2014),"The role of islamic values on green purchase intention", Journal of Islamic Marketing, Vol. 5 No. 3 pp. 1-25.

Hofstede, G. (1995), "Insurance as a product of national values", Geneva Papers on Risk and Insurance - Issues and Practice, Vol. 20, No. 4, pp. 423-429.

Hubbard, R.G., Skinner, J. and Zeldes, P. (1995), "Precautionary saving and social insurance", Journal of PoliticalEconomy, Vol. 103, No. 2, pp. 360-399.

Hwang, T. and Gao, S. (2003), "The Determinants of the demand for life insurance in an emerging economy -The case of China", Journal of Managerial Finance, Vol. 29, No. 5/6, pp. 82-96.

Karni, E. and Zilcha, I. (1986), "Risk aversion in the theory of life insurance: The Fisherian model", Journal of Risk and Insurance, Vol. 53, No. 4, pp. 606-620.

Khan, M.S.U. and Uddin, M.N. (2013), "Insurance industry in Bangladesh: Opportunities and challenges", Thoughts on Economics, Vol. 23, No. 04, pp. 55-78.

Kogan, N. and Wallach, M.A. (1964), Risk Taking: A Study of Cognition and Personality, Holt, Rinehart \& Winston, New York (N.Y.) 
Business Review- A Journal of Business Administration Discipline, Khulna University, Volume: 13, Number: 1E2,January-December 2018, pp.13-28 (Print ISSN : 1811-3788; Online ISSN : 2664-3502)

Liebenberg, A.P., Carson, J.M. and Dumm, R.E. (2012), "A dynamic analysis of the demand for life insurance", Journal of Risk and Insurance, Vol. 79, No. 3, pp. 619-644.

Lusardi, Mitchell and Curto, (2010), "Financial literacy among the young", Journal ofConsumer Affairs, Vol. 44, No. 2, pp. 358-380.

Mahdzan, N.S. and Victorian, S.M.P. (2013), "the determinants of life insurance demand: A focus on saving motives and financial literacy", Asian Social Science, Vol. 9, No. 5, pp. 274-284

Malhotra, N. K. (2010), Marketing Research: An Applied Orientation, Dorling Kindersley Pvt. Ltd, India.

Mamun, M.Z. (2013), "Problems and Prospects of Insurance Business in Bangladesh: The Companies' Perspective", paper presented at the Fifteenth Annual Conference of Asia-Pacific Risk and Insurance Association, April 2013, St. John's University, New York, U. S. A.

Mamun, Z.M. (2014), Ethical Standards in Life Insurance Companies in Bangladesh: The Policy Holders' View. [Online] $1^{\text {st }}$ July 2015. Available from http://www.wriec.net/wpcontent/uploads/2015/07/1I3_Mamun.pdf.(Accessed: 20th August 2018).

Mandrik, C.A. and Bao, Y. (2005), "Exploring the concept and measurement of general risk aversion", Association for Consumer Research, Vol. 32, pp. 531-539.

Mantis, G. and Farmer, R. (1968), "Demand for life insurance", Journal of Risk and Insurance, Vol. 35, No. 2, pp. 247-256.

Matzler, K., Krauter, S.G. and Bidmon, S. (2008),"Risk aversion and brand loyalty: The mediating role of bran trust and brand affect", Journal of Product \& Brand Management, Vol. 17, No. 3, pp. 154-162.

Mimović, P., Jakšić, M. and Todorović, V. (2017), “ Choice of Life Insurance Companies by Using Analytic Hierarchy Process: Experience of the Republic of Serbia", Journal of Insurance and Financial Management, Vol. 3, No. 1, pp. 1-18.

Modigliani, F. and Brumberg, R. (1954), "Utility analysis and the consumption function: an interpretration of cross section data”, In Kurihara, K. (Ed.), Post-Keynesian Economics. Rutgers University Press, New Brunswick, New Jersey.

Nekmahmud M., Shahedul A.S.M. and Ferdush R. M. (2017), "Measuring people's attitude towards the life insurance in Rangpur city corporation in Bangladesh", International Journal of Economics \&Management Sciences, Vol. 6, No.2, pp. 1-6.

Nesterova, D. (2008), "Determinants of the demand for life insurance: Evidence from selected CIS and CEE countries". National University "Kyiv-Mohyla Academy”, pp. 1-49.

Omar, O.E. and Owusu, F.N. (2007), "Life insurance in Nigeria: An application of the theory of reasoned action to consumers' attitudes and purchase intention”, The Service Industries Journal, Vol. 27 No. 7, pp. 963-976.

Outreville, J.F. (2014), "Risk aversion, risk behavior, and demand for insurance: A survey", Journal of Insurance Issues, Vol. 37, No. 2, pp. 158-186.

Outreville, J.F. (1998), "Risk Aversion and Insurance", Theory and Practice of Insurance, Springer, Boston, MA, pp. 113-130.

Raviv, A. (1979), "The design of an optimal insurance policy”, American Economic Review, Vol.69, No. 1, pp. 223-239.

Ray, S. and Ali, S. (2008), "Gap analysis between customer's expectation and current provisions of Indian life insurance industry”, ICFAI Journal of Consumer Behavior, Vol. 3, No. 3, pp. 33-46.

Raza, A., Farhan, M. and Akram, M. (2011), "A Comparison of financial performance in investment banking sector in Pakistan", International Journal of Business and Social Science, Vol. 2, No. 9, pp. 72-81.

Rha, J. Y., Montalto, C.P. and Hanna, S. D. (2006), "The Effect of Self-Control Mechanismson Household Saving Behavior", Financial Counseling and Planning, Vol.17, No. 2, pp. 3-16.

Rousseau, D.M. et al. (1998), "Not so different after all: a cross-discipline view of trust", Academy of Management Review, Vol. 23, No. 3, pp. 393-404.

Savvides, S. (2006), "Inquiry into the macroeconomic and household motives to demand life insurance: Review and empirical evidence from Cyprus", Journal of Business and Society, Vol. 19, pp. 37-79.

Schooley, D.K. and Worden, D.D. (1996), "Risk aversion measures: Comparing attitudes and asset allocation", Financial Services Review, Vol. 5, No. 2, pp. 87-99. 
Business Review- A Journal of Business Administration Discipline, Khulna University, Volume: 13, Number: 1E2,January-December 2018, pp.13-28 (Print ISSN : 1811-3788; Online ISSN : 2664-3502)

Shafii, Z., Abiddin, Z. and Ahmad, A. R. (2009), "Ethnic heterogeneity in the Malaysian economy: A special reference to the ethnic group participation in financial planning activities", Journal of International Social Research, Vol. 2, No. 8, pp. 394-401.

Szpiro, G. G. (1986), "Measuring risk aversion: An alternative approach", Review of Economics and Statistics, Vol.68, No. 1, pp. 156-159.

Todd, J.D. (2004), "Integrative life insurance need analysis", Journal of Society of Financial Service Professionals. [Online] Vol. 58, No. 2, Available from: http://connection.ebscohost.com/c/articles/12400365/integrative-lifeinsurance-needs-analysis [Accessed: 20th July 2018]

Truett, D. B. and Truett, L. J. (1990), "The demand for life insurance in Mexico and the United States: A comparative study", Journal of Risk and Insurance, Vol. 57, No. 2, pp. 321-328.

Ward, D. and Zurbruegg, R. (2000), "Does insurance promote economic growth? Evidence from OECD countries", Journal of Risk and Insurance, Vol.67, No. 4, pp. 489-506.

Wärneryd, K.E. (1999), The psychology of saving: A study on economic psychology. Edward Elgar Publishing, Glos.

Yazid, A.S. et al (2012), "Determinants of family takaful (islamic life insurance) demand: A conceptual framework for a Malaysian Study", International Journal of Business and Management, Vol. 7 No. 6, pp. 115-127.

Yusof, T.O., Gbadamosi, A. and Hamadu, D. (2009), "Attitudes of Nigerians towards insurance services: An empirical study", African Journal of Accounting, Economics, Finance, and Banking Research, Vol.4, No. 4, pp. 34-46.

Zakaria, Z. et al. (2016), "The Intention to purchase life insurance: A case study of staff in public universities", Procedia Economics and Finance, Vol. 37, pp. 358 - 365.

\section{Appendix:}

Questionnaire

\begin{tabular}{|c|c|c|}
\hline SL & Items & Sources \\
\hline \multicolumn{3}{|c|}{ Demographic variables } \\
\hline 01 & Age & $\begin{array}{l}\text { J. Y. Rha, C. P. Montalto and S. D. } \\
\text { Hanna (2006) } 3\end{array}$ \\
\hline 02 & Income & Simona Laura Dragos (2014) 1 \\
\hline 03 & Education & Simona Laura Dragos (2014) 1 \\
\hline 04 & Marital Status & Mahdzan\& Victorian (2013) 2 \\
\hline 05 & Dependents & Mahdzan\& Victorian (2013) 2 \\
\hline 06 & Urbanization & Simona Laura Dragos (2014) 1 \\
\hline 07 & Gender & Delafrooz\&LailyPaim (2011) 4 \\
\hline & Financial Literacy & \\
\hline 01 & I fully understand the life insurance plan & \multirow{4}{*}{ Mahdzan\& Victorian (2013) 2} \\
\hline 02 & I understand the riskiness of life insurance plan & \\
\hline 03 & I think life insurance best satisfies my financial needs & \\
\hline 04 & $\begin{array}{l}\text { I know about other financial products that might satisfy my financial } \\
\text { needs }\end{array}$ & \\
\hline \multirow[t]{3}{*}{05} & I understand the financial phrases and symbols of life insurance plan & SitiHasnah Hassan, (2014) 5 \\
\hline & Saving Motives & \\
\hline & Lifecycle motives & \\
\hline 01 & I purchased/will purchase life insurance plan for children's education & \multirow[b]{2}{*}{ Mahdzan\& Victorian (2013) 2} \\
\hline 02 & $\begin{array}{l}\text { I purchased/will purchase life insurance plan for securing my } \\
\text { retirement period }\end{array}$ & \\
\hline
\end{tabular}


Business Review- A Journal of Business Administration Discipline, Khulna University, Volume: 13, Number: 1E2,January-December 2018, pp.13-28 (Print ISSN : 1811-3788; Online ISSN : 2664-3502)

\begin{tabular}{|c|c|c|}
\hline 03 & $\begin{array}{l}\text { I purchased/will purchase life insurance plan for bearing my wedding } \\
\text { expenses }\end{array}$ & \\
\hline 04 & I purchased/will purchase life insurance plan for a new-born child & \\
\hline & Precautionary motives & \\
\hline 01 & I purchased/will purchase life insurance plan for emergency purposes & \multirow{3}{*}{ Mahdzan\& Victorian (2013) 2} \\
\hline 02 & I purchased/will purchase life insurance plan for a rainy day & \\
\hline \multirow[t]{2}{*}{03} & $\begin{array}{l}\text { I purchased/will purchase life insurance plan for the unfortunate } \\
\text { event of disability }\end{array}$ & \\
\hline & Bequest motives & \\
\hline 01 & $\begin{array}{l}\text { I purchased/will purchase life insurance plan becau+se there is no } \\
\text { breadwinner after me }\end{array}$ & \multirow{3}{*}{ Mahdzan\& Victorian (2013) 2} \\
\hline 02 & $\begin{array}{l}\text { I purchased/will purchase life insurance plan because I want to leave } \\
\text { it as an inheritance }\end{array}$ & \\
\hline \multirow[t]{2}{*}{03} & $\begin{array}{l}\text { I purchased/will purchase life insurance plan as a continuity of } \\
\text { income upon my death }\end{array}$ & \\
\hline & Wealth accumulation motives & \\
\hline 01 & I purchased/will purchase life insurance plan as a form of savings & \multirow{4}{*}{ Mahdzan\& Victorian (2013) 2} \\
\hline 02 & $\begin{array}{l}\text { I purchased/will purchase life insurance plan to obtain guaranteed } \\
\text { returns from it }\end{array}$ & \\
\hline 03 & I purchased/will purchase life insurance plan for its bonuses it pay & \\
\hline \multirow[t]{2}{*}{04} & I purchased/will purchase life insurance plan for dividends it pay & \\
\hline & Risk aversion motives & \\
\hline 01 & In case of decision making I would like to take minimum risk & \multirow{3}{*}{ Schooley\& Worden (1996) 6} \\
\hline 02 & In case of decision making I would like to take average risk & \\
\hline 03 & In case of decision making I would like to take above average risk & \\
\hline & Purchase Intention & \\
\hline 01 & I think having a life insurance plan should be compulsory for all & \multirow{3}{*}{ Self-administered } \\
\hline 02 & $\begin{array}{l}\text { Purchasing a life insurance plan will provide me future surety which } \\
\text { I need most for my inheritance }\end{array}$ & \\
\hline 03 & $\begin{array}{l}\text { I think government should take initiatives to make the plan purchased } \\
\text { by general people }\end{array}$ & \\
\hline
\end{tabular}

